\title{
Superior Tribunal Militar: Entre o Autoritarismo e a Democracia*
}

Jorge Zaverucha

Hugo Cavalcanti Melo Filho

\section{INTRODUÇÃO}

\footnotetext{
Q
} uando os militares e seus aliados na sociedade civil se convencem ou são convencidos de que devem devolver as rédeas do poder à oposição civil, é natural que vários atores políticos, sejam civis e/ou militares, procurem negociar a proteção de seus interesses ante o novo governo que se avizinha. Neste artigo, os atores que nos interessam são as Forças Armadas e o Judiciário. O interesse a ser defendido é a continuação da presença castrense no Judiciário. Mais especificamente, a atuação do Superior Tribunal Militar - STM como uma corte que defende, primordialmente, os interesses institucionais das Forças Armadas relativos aos bens tutelados que lhes são importantes: hierarquia, disciplina e dever militar.

Diferentemente de outros atores políticos, as Forças Armadas detêm a capacidade de reverter, pelas armas, o processo de democratização. Por isso mesmo, seu peso na barganha política é maior do que o dos outros atores, em especial, no caso brasileiro, em que as Forças Arma-

* Gostaríamos de agradecer aos pareceristas anônimos de Dados e a Roberto Kant de Lima por suas valiosas sugestões.

DADOS - Revista de Ciências Sociais, Rio de Janeiro, Vol. 47, nํ4, 2004, pp. 763 a 797. 
das negociaram sua saída do governo em bom estado político - ao contrário, por exemplo, da Argentina, onde os militares perderam fragorosamente a Guerra das Malvinas, foram protagonistas de vários golpes palacianos e gozavam de grande impopularidade, mercê da feroz repressão praticada pelas Forças Armadas.

A manutenção de graus de autonomia política pelos militares, variando de intensidade de acordo com cada país, é o preço pago pelos democratas para assegurar a concordância castrense em devolver o governo aos civis ${ }^{1}$. Essa autonomia, todavia, deve ser temporária caso se almeje avançar rumo a uma democracia plena. Plena no sentido de que não apenas as instituições eleitorais funcionem democraticamente, mas também as instituições coercitivas. Para o presente artigo, as Forças Armadas e o Judiciário.

Este artigo procurará mostrar como, decorridos quase vinte anos do fim do regime autoritário, os militares seguem exercendo esse tipo de autonomia no aparelho de Estado. Uma das provas desse poder castrense reside no fato de o STM continuar sendo um enclave autoritário $^{2}$ incrustado estrategicamente no Judiciário. Ou seja, o STM é um tribunal com características híbridas, pois apresenta traços tanto do regime autoritário como da frágil democracia em que vivemos ${ }^{3}$. Tentaremos mostrar como esse hibridismo se manifesta e suas implicações danosas para o avanço da democracia. Ao final, procuraremos explicar o porquê dessa situação.

\section{O ESTADO DA ARTE}

Nos estudos sobre transições do autoritarismo para a democracia, a dimensão militar tem sido constantemente negligenciada. Isto se deve, em boa medida, ao conceito de Schumpeter (1942) sobre democracia. Para ele, a democracia é minimalista no sentido de que "pode suportar, na melhor das hipóteses, apenas um envolvimento político mínimo: aquele tipo de envolvimento que poderia ser considerado suficiente para legitimar o direito das elites políticas em condições de competir para governar" (Held, 1987:153).

Os adeptos da concepção minimalista focam sua atenção nas eleições. Confundem democracia eleitoral com regime democrático. E por isso não dão importância às instituições coercitivas, como as Forças Armadas e o Judiciário, pois elas não são submetidas ao crivo da com- 
petição eleitoral. Desse modo, é comum encontrar-se a afirmação de que a democracia brasileira está consolidada, haja vista os avanços obtidos no nosso sistema eleitoral. Por exemplo, Bresser Pereira escreveu que "em 1985 o país completou sua transição democrática; em 1988 consolidou-a com a aprovação da Constituição" (1998:240).

Discordamos da ênfase dada ao componente eleitoral da democracia. Eleição é condição necessária, mas não suficiente para se dizer que há uma democracia consolidada. Há outros fatores a serem levados em consideração. Limitar-nos-emos a um deles: o controle civil democrático sobre os militares ${ }^{4}$. Para os propósitos deste artigo, realçaremos o notável poder de interferência que as Forças Armadas possuem no trato de seus interesses institucionais no âmbito do Poder Judiciário.

A importância de existir o controle civil sobre os militares reside, portanto, no fato de se garantir aos governantes eleitos a efetiva capacidade de governar. Przeworski et alii (2000), influenciados por Schumpeter, rechaçam esse critério. Para eles, as classificações dos regimes não se devem basear em juízos sobre o exercício real do poder. Chegam a afirmar que,

“[...] em algumas democracias (de que Honduras e Tailândia são protótipos), o governo civil não é mais que uma delgada camada encobrindo o poder militar que é, de fato, exercido por generais reformados. Mas enquanto os governantes forem eleitos em eleições nas quais outros grupos tenham a chance de vencer e enquanto não usarem o poder dos seus cargos para eliminar a oposição, o fato de o chefe do Executivo ser um general ou um serviçal de general não acrescenta nenhuma informação relevante" (idem:35).

Mainwaring et alii (2001), por sua vez, discordam da visão de Przeworski e chamam sua concepção sobre democracia de subminimalista. Uma concepção dicotômica, pois só admite dois mundos possíveis: democracia e não-democracia. Para Mainwaring, há uma situação intermediária que ele define como sendo semi(democracia)(autoritarismo $)^{5}$. Ou seja, há países que não podem ser definidos como democracias plenas nem como totalmente autoritários. São regimes híbridos, por apresentarem características tanto democráticas como autoritárias no funcionamento de suas instituições.

Nessa zona híbrida entre o autoritarismo e a democracia, advogamos, encontra-se o Brasil. Zaverucha $(1994 ; 2000)$ já indicou vários exem- 
plos de como os militares brasileiros dificultam e, às vezes, impedem a efetiva capacidade de civis governarem. No entanto, não existe nenhum estudo sobre o comportamento do STM, visto sob essa perspectiva. É o que nos propomos a fazer.

\section{A ORIGEM DO STM}

O Superior Tribunal Militar tem suas origens no Alvará de 1ํ de abril de 1808, do então príncipe regente de Portugal, Dom João, que criou o Conselho Supremo Militar e de Justiça, com sede na cidade do Rio de Janeiro. Tal Conselho exercia funções administrativas e judiciárias, julgando, em última instância, os processos criminais dos réus sujeitos ao foro militar.

O Conselho Supremo Militar e de Justiça era integrado por treze membros: quatro conselheiros de Guerra e do Almirantado de Portugal, seis oficiais nomeados como vogais (os quais, na maioria das vezes, galgavam à posição de Conselheiro de Guerra) e três juízes togados, um dos quais para relatar os processos. Todos nomeados livremente pelo monarca ${ }^{6}$. A Constituição do Império, de 1824, não trouxe disposições acerca da jurisdição militar, sendo a matéria regulada no âmbito da legislação ordinária.

Após o advento da República, deu-se a extinção do Conselho Supremo Militar. A Carta republicana, de 1891, não inseriu, no título destinado ao Poder Judiciário, nenhuma referência à Justiça Militar, apenas prevendo, em seu artigo 77, foro especial para os crimes militares, estruturado em um Supremo Tribunal Militar e Conselhos destinados ao julgamento de delitos. A organização da corte seria estabelecida em lei ordinária. Criavam-se, assim, órgãos judicantes de natureza especial, não integrados ao Poder Judiciário, fato que viria a se repetir em 1934, com a instituição da Justiça do Trabalho, de natureza administrativa.

Segundo Bastos (1981), até 1893, a presidência do Conselho era exercida pelo chefe de Estado; por ela passaram, portanto, o príncipe regente Dom João, os imperadores Pedro I e Pedro II, e os marechais Deodoro da Fonseca e Floriano Peixoto.

Em 18 de junho de 1893, pelo Decreto Legislativo no 149, foi criado o Supremo Tribunal Militar, com a mesma competência antes atribuída ao Conselho Supremo Militar, mas com composição de quinze minis- 
tros, sendo quatro da Armada, oito do Exército e três togados. Também foi regulado, pelo mesmo decreto, o exercício da presidência do Tribunal, que coube ao "general" mais graduado que dele fizesse parte (idem).

O Decreto no 14.450, de 30 de outubro de 1920, que instituiu o Código de Organização Judiciária e Processo Militar, reduziu a nove o número de ministros do STM, sendo dois da Armada, três do Exército e quatro togados, estes escolhidos entre os auditores de segunda entrância ou entre bacharéis em direito com seis anos de prática, de preferência magistrados. $\mathrm{O}$ mesmo decreto inovou ao prescrever a eleição do presidente e do vice-presidente da corte.

Em 1926 ocorreu nova alteração. O Decreto no 17.231-A, que baixou o Código de Justiça Militar, aumentou para dez o número de ministros, agora três do Exército, dois da Armada e cinco entre magistrados e bacharéis em direito.

Foi a Constituição de 1934 que atribuiu ao Supremo Tribunal Militar o status de órgão do Poder Judiciário. Com isso foi eliminada a competência administrativa, mantendo-se a função jurisdicional. Permaneceu, todavia, na esfera infraconstitucional o disciplinamento de sua estrutura e funcionamento. Nesse mesmo ano, o número de ministros foi, mais uma vez, aumentado, passando a onze (Decreto nํ2 24.802, de 14 de julho): quatro do Exército, três da Armada e quatro civis, dos quais três escolhidos entre auditores e um, entre cidadãos de notório saber em ciências sociais.

A criação do Ministério da Aeronáutica, em 1941, exigiu nova modificação na estrutura do Supremo Tribunal Militar, para inclusão de integrantes daquela Força. O Decreto no 4.235, de 6 de abril do mesmo ano, manteve em onze o número de membros, sendo três do Exército, dois da Armada, dois da Aeronáutica e quatro civis.

Com a redemocratização, a corte de cúpula passou a se denominar Superior Tribunal Militar, por força da mudança promovida pela Carta Constitucional de 1946. Permaneceu na esfera ordinária o disciplinamento quanto à estrutura da corte.

Em 1961 foi instituído, pelo próprio Tribunal, o rodízio entre as três Armas na presidência do órgão ${ }^{7}$. 
O Ato Institucional nํ2, de 1965, modificou o texto da Constituição de 1946, ampliando para quinze membros a composição do STM, tal como no início do período republicano (Decreto no 149/1893), sendo quatro do Exército, três da Marinha, três da Aeronáutica e cinco civis. A Constituição de 1967 incorporou o texto do AI-2, transferindo para o corpo constitucional o disposto sobre a composição do STM (Soares, 1994/1996).

Em maio de 1965 ocorreu fato inédito na história da corte: um ministro civil assumiu, ainda que interinamente, sua presidência. O ministro Washington Vaz de Mello ocupou o cargo por três meses, em virtude de doença do então titular, até a eleição do sucessor ${ }^{8}$.

A organização e o funcionamento da Justiça Militar são disciplinados pela Lei n-8.457, de 4 de setembro de 1992. No referido diploma, o artigo 1ํ- define como órgãos da Justiça Militar: o STM; a Auditoria de Correição; os Conselhos de Justiça; os Juízes-Auditores; e os Juízes-Auditores Substitutos 9 . Todas as Auditorias, bem como o STM, têm jurisdição mista, competindo-lhes, portanto, processar e julgar os crimes militares praticados por civis e/ou militares integrantes das Forças Armadas (Costa Filho, 1994/1996).

\section{A INSÓLITA COMPOSIÇÃO DO STM}

Até 1934, o então chamado Supremo Tribunal Militar tinha atribuições administrativas concorrentes com a função jurisdicional, herança do Conselho Supremo Militar. Com a Constituição daquele ano, a corte passou a integrar o Poder Judiciário da União, abandonando a feição administrativa ${ }^{10}$.

Não é de estranhar que, no exercício de funções administrativas, "coadjuvando o governo em questões referentes a requerimentos, cartas-patentes, promoções, soldos, reformas, nomeações, lavratura de patentes e uso de insígnias, sobre as quais manifestava seu parecer" (Bastos, 1981:21), fosse o Conselho - e, depois, o Supremo Tribunal Militar - constituído majoritariamente por militares.

Para o julgamento dos processos criminais, aos militares juntavam-se três ministros togados - um relator e dois adjuntos -, para o despacho de todos os processos remetidos ao Conselho de Justiça ${ }^{11}$. Como não poderia deixar de ser, a matéria jurídica era enfrentada e relatada por magistrados com formação jurídica. Os militares apenas votavam. 
Com a prevalência da função jurisdicional do Supremo Tribunal Militar, a partir de 1893, observou-se natural tendência à redução do número de ministros militares e à ampliação da quantidade de ministros civis, levada a cabo em 1920. Além disso, a norma que regia a matéria estabelecia a exigência de conhecimento jurídico aos membros civis, que deveriam ser escolhidos entre auditores e advogados com ao menos seis anos de prática, de preferência magistrados. Na mesma linha seguiu a Constituição de 1926, que igualou o número de membros civis ao de militares. Aqueles seriam advindos da magistratura, podendo, ainda, ser escolhidos entre auditores, membros do Ministério Público ou membros da advocacia. Nítida, por razões óbvias, tratando-se de um tribunal, a opção prioritária por magistrados de carreira nesse período.

Sob a ditadura Vargas, dá-se uma reversão na tendência; curiosamente, quando a Justiça Militar passa a integrar o Poder Judiciário e se elimina a vertente administrativa de sua atividade, portanto, no instante em que nada mais justificaria a presença de militares em sua composição, desequilibra-se a relação numérica em favor destes. A Constituição de 1934 não faz mais menção à preferência por magistrados, dispondo que a escolha dos membros civis se dará entre auditores e um cidadão de notável saber na área de ciências sociais.

Injustificadamente, a redemocratização do país, em 1946, não alterou o quadro. Mantiveram-se os critérios e as quantidades. Sob novo regime autoritário, a partir de 1965, amplia-se drasticamente o número de ministros militares e, na prática, elimina-se a participação de magistrados de carreira na composição do então Superior Tribunal Militar.

Por sua vez, a Emenda Constitucional no 1, de 17 de outubro de 1969, seguida pela de no $7 / 77$, permitiram que o STM funcionasse em turmas. Isto, infelizmente, não foi posto em prática até os dias de hoje. $\mathrm{O}$ STM é a exceção em relação aos outros tribunais superiores ${ }^{12}$. Outro aspecto curioso diz respeito ao quórum mínimo para a reunião plenária da corte. Existindo, atualmente, dez ministros militares e cinco ministros civis no STM, nas sessões de julgamento ou administrativas, nos termos do Regimento Interno do Tribunal, artigo 65, é necessária a presença mínima de oito ministros, sendo, no mínimo, quatro militares e dois civis. Isto embora os ministros civis sejam os detentores dos conhecimentos técnicos. O presidente da sessão pode ser tanto 
um ministro militar quanto um ministro civil. Significa dizer que se, por exemplo, estiverem presentes três militares e cinco civis não haverá sessão. Mas, a sessão pode ser iniciada com a presença de seis militares e dois civis. Com tal regra, a tendência é a de que não se realizem sessões sem a garantia da maioria dos militares, salvo na remota hipótese de estarem presentes todos os cinco ministros civis e apenas quatro ministros militares.

Findo o regime militar, a Constituição de 1988 conservou a hegemonia castrense e a exclusão da magistratura. No Superior Tribunal Militar, dos quinze ministros, dez são oficiais-generais e cinco são civis. Destes, três são escolhidos entre advogados; dos outros dois, um virá do Ministério Público Militar, o outro será escolhido entre os juízes-auditores (o único juiz de carreira, portanto). E mais: somente militares no mais alto grau da carreira podem se tornar ministros do STM. Ou seja, um general-de-exército sem qualquer conhecimento jurídico está apto a ser ministro, mas um coronel da ativa bacharel em direito não pode ser indicado. É a hierarquia militar prevalecendo sobre o conhecimento jurídico em um órgão do Poder Judiciário. Não se pode olvidar, ainda, que o presidente da República, na condição de comandante-em-chefe das Forças Armadas, situa-se em posição hierárquica superior aos ministros militares - já que estes mantêm as patentes -, o que não deixa de ser situação deveras curiosa, considerada a independência que deve marcar o relacionamento entre os Poderes da República.

Mesmo perdendo competências desde 1979, quando deixou de apreciar crimes políticos, o STM continua, basicamente, com a mesma estrutura criada durante o regime militar. Ser nomeado para o STM é, na caserna, como adquirir a "quinta estrela"13. O ministro ganha cerca do dobro do que ganharia na caserna, passa a ter remuneração superior à do presidente da República, além de se aposentar como magistrado, em vez de militar. Nos gabinetes do STM, contarão com os préstimos de praças cedidos pelo Exército, situação que já lhes gerou constrangimentos. $\mathrm{O}$ ex-ministro do Exército Zenildo Lucena, ao saber que o STM decidira não aceitar a indicação do coronel da reserva João Fagundes para uma vaga civil ${ }^{14}$, requisitou trinta militares que trabalhavam no STM como estafetas, motoristas etc. 


\section{O ALIJAMENTO DO JUDICIÁRIO NO PROCESSO DE ESCOLHA}

No sistema constitucional brasileiro, excluída a hipótese de nomeação para o Supremo Tribunal Federal -STF e o Superior Tribunal Militar, da escolha dos membros dos tribunais, inclusive os superiores, participa, necessariamente, a própria corte. A idéia é a da participação do três Poderes na seleção dos integrantes das cortes. No Superior Tribunal de Justiça e no Tribunal Superior do Trabalho, as vagas que surgem são preenchidas por juízes togados, ocasião em que os próprios tribunais elaboram listas tríplices a serem encaminhadas ao presidente da República, ou por integrantes da carreira da advocacia ou do Ministério Público - quinto constitucional -, circunstância em que os tribunais recebem listas sêxtuplas dos órgãos corporativos respectivos, para redução a listas tríplices. No STM nada disso ocorre. A corte não participa do processo de escolha. Tanto os ministros militares quanto os civis são indicados à revelia do STM.

Propostas no sentido de que a própria corte viesse a participar da escolha dos seus membros - os civis, diga-se - malograram na reforma do Judiciário que acaba de ser aprovada na Câmara, como será explicitado adiante, de modo que o STM continuará sendo bizarra estrutura judiciária, de cuja composição o Poder Judiciário não participa.

Será que o argumento de resguardar os princípios da hierarquia e da disciplina que devem reger as Forças Armadas justifica a existência de estrutura judiciária especial para os militares, vis-à-vis os demais cidadãos civis? Como se pode assegurar imparcialidade a uma corte composta, de forma majoritária, pelos pares do réu?

Os critérios constitucionalmente fixados para o recrutamento de juízes para a Justiça Militar operam contra a garantia da independência judicial. Procura-se assegurar a preponderância dos militares nas cortes, criando-se ambiente propício para ingerências da caserna, com natural ameaça à imparcialidade. Como bem lembra Dallari "Ainda perdura a situação privilegiada do Exército na organização nacional, inclusive pela garantia de tratamento diferençado quanto à responsabilidade perante a justiça [...] que se estendeu aos demais ramos das Forças Armadas" (1996:134).

Se com a interveniência dos tribunais na seleção dos seus membros a interferência política é notória, quando se exclui a participação das cortes tal ingerência se potencializa. Isto porque a base de escolha é 
elastecida. É o que se verifica com facilidade no STM, principalmente quando se trata de ministro oriundo da classe dos advogados. Equipara-se, assim, no particular aspecto da absoluta discricionariedade do presidente da República, o STM ao STF, órgão de cúpula do Poder Judiciário. Ao se comparar o STM às demais cortes de competência similar, nota-se a omissão de importantes requisitos fixados constitucionalmente para o acesso aos demais tribunais superiores, como veremos a seguir.

\section{FUGINDO À REGRA: A PERMANÊNCIA DO MINISTRO-OFICIAL NA ATIVA}

O artigo 9o da Lei ํㅡ 6.880/80, que instituiu o Estatuto dos Militares, dispõe que os oficiais-generais nomeados ministros do Superior Tribunal Militar são regidos por legislação específica. Ainda assim, cumpre examinar as regras a que se submetem os militares para que se demonstre que a permanência dos oficiais nomeados ministros do STM na atividade constitui casuísmo inexplicável.

O artigo 3으, § 2을 da mesma lei determina que o militar somente pode se encontrar em duas situações: na ativa ou na inatividade. Na ativa encontram-se os de carreira; os incorporados às Forças Armadas para prestação de serviço militar inicial; os componentes da reserva das Forças Armadas quando convocados, reincluídos, designados ou mobilizados; os alunos de órgão de formação de militares da ativa e da reserva; e, em tempo de guerra, todo cidadão brasileiro mobilizado para o serviço ativo nas Forças Armadas.

Já na inatividade se situam os da reserva remunerada, quando pertencem à reserva das Forças Armadas e percebem remuneração da União, estando porém sujeitos à prestação de serviço na ativa, mediante convocação ou mobilização, e os reformados, quando, tendo passado por uma das situações anteriores, estejam dispensados, definitivamente, da prestação de serviço na ativa, mas continuem a perceber remuneração da União.

Prevê o Estatuto dos Militares, no artigo 80, a hipótese da agregação, "situação na qual o militar da ativa deixa de ocupar vaga na escala hierárquica de seu Corpo, Quadro, Arma ou Serviço, nela permanecendo sem número". O artigo 81 enumera os casos em que a mesma ocorrerá, sendo uma delas a do militar que "houver ultrapassado 6 (seis) meses contínuos na situação de convocado para funcionar como mi- 
nistro do Superior Tribunal Militar" (inciso V). Logo, o oficial convocado para substituir o ministro do STM em seus impedimentos, permanecendo nesta situação por mais de seis meses, considerar-se-á agregado.

Nos termos do artigo 82, o militar será, ainda, agregado quando for afastado temporariamente do serviço ativo, entre outros, por motivo de:

“XII - ter passado à disposição de Ministério Civil, de órgão do Governo Federal, de Governo Estadual, de Território ou Distrito Federal, para exercer função de natureza civil;

XIII - ter sido nomeado para qualquer cargo público civil temporário, não-eletivo, inclusive da administração indireta;"

Significa dizer que o militar que exerça função de natureza civil ou cargo público em qualquer órbita da administração será agregado, podendo, a qualquer tempo, ser determinada a sua reversão à Força.

O oficial-ministro do STM não fica agregado, nem passa à reserva. A situação é curiosa. Em outras hipóteses, a permanência em afastamento por mais de dois anos, "agregado em virtude de ter passado a exercer cargo ou emprego público civil temporário, não-eletivo, inclusive da administração indireta", determina a transferência para a reserva remunerada, ex officio, conforme dispõe o artigo 98 do Estatuto dos Militares.

O artigo 3ํㅡㄹ da Lei no 8.457/92 repete os termos do artigo 123 da Constituição Federal, com o acréscimo de apenas um parágrafo, que assim dispõe: "§ 2 - - Os Ministros militares permanecem na ativa, em quadros especiais da Marinha, do Exército e Aeronáutica". Tal disposição cria situação em tudo distinta do regramento geral fixado para os militares que exercem funções ou cargos de natureza civil, em qualquer esfera da administração pública, vide o caso do ministro Carlos de Almeida Batista. Após presidir o STM, foi nomeado, pelo ex-presidente Fernando Henrique Cardoso, comandante da Aeronáutica, com o que se deu a sua passagem para a inatividade, seguida de convocação para o serviço ativo. A contradição está em que para ser ministro do STM o militar precisa estar em atividade, mas para comandar a Arma, não. 
O que justifica a situação híbrida de ser magistrado, do órgão de cúpula da Justiça Militar e, ao mesmo tempo, ocupar o posto mais elevado da carreira militar? Por que se conjuga, de modo único, a experiência da farda com os conhecimentos jurídicos da toga? Na visão dos militares, é a hierarquia que deve reger as suas relações. Assim, não poderia o oficial julgar outro oficial se estivesse em situação de inferioridade hierárquica, o que seria provocado pela inatividade. Olvida-se, entretanto, o aspecto óbvio de que, no STM, não mais se processam os feitos de natureza administrativa, como fazia o antigo Conselho Supremo Militar. Sendo a corte órgão jurisdicional, não há como falar em vínculo hierárquico entre julgador e jurisdicionado. Assim deve ser no Estado de direito democrático.

\section{MILITARES NOS QUARTÉIS E, QUANDO CONVENIENTE, NO TRIBUNAL}

Não está em discussão, aqui, a legitimidade da Justiça Militar. Admitindo-se a necessidade da existência da legislação penal militar, da Justiça Militar e de tribunais militares, o que justifica serem os mesmos constituídos por militares? É isso o que se pretende examinar.

Obtempera o ministro Moreira Alves que "o juiz singular, por mais competente que seja, não pode conhecer as idiossincrasias da carreira das armas, não estando em condições de ponderar a influência de determinados ilícitos na hierarquia e disciplina das Forças Armadas"15.

O argumento é semelhante ao utilizado pelos defensores da representação classista para justificar sua permanência nos órgãos da Justiça do Trabalho: tratando-se de estrutura especializada da Justiça, destinada a julgar os conflitos decorrentes da relação entre capital e trabalho, imprescindível seria a existência de representantes de empregados e empregadores, para trazer a experiência da relação de trabalho para o seio do órgão julgador.

Nada mais equivocado. A aplicação da hipótese legal aos fatos não pressupõe o conhecimento prévio destes pelo julgador. Tampouco intimidade com o ambiente onde eles ocorrem. Nem hierarquia entre julgador e jurisdicionado. Se assim fosse, os crimes cometidos por padres teriam de ser julgados pelo bispo; por funcionários públicos, pelo chefe da repartição; por agentes da Polícia Civil, pelo delegado (Melo Filho, 2002). 
No caso dos militares, se lhes sobra conhecimento da realidade da caserna, faltam-lhes, por completo, conhecimentos jurídicos, preparo técnico, este sim essencial. No STM, os ministros militares, em geral, não têm formação jurídica. Tanto é que os pareceres técnicos são preparados por suas assessorias, compostas por bacharéis em direito. Entre os civis, salvo o magistrado de carreira e o membro do Ministério Público, nada assegura que os advogados tenham profundo conhecimento do Direito Penal Militar.

O ministro Carlos Alberto de Almeida Batista, em discurso na Câmara dos Deputados, afirmou que "a questão da competência técnica dos membros dos tribunais castrenses encontra fácil resposta na composição dos Tribunais e dos Conselhos de Justiça [...]. O senso de justiça não pertence somente aos bacharéis em Direito; ele é inerente ao ser humano $[\ldots]^{\prime \prime 16}$. Ora, assim como ao arquiteto não basta saber desenhar, ao julgador não basta o senso de justiça. Ele é necessário, mas não suficiente. A técnica é imprescindível.

O reconhecimento de tal evidência fez com que, desde o nascedouro, na corte militar, o relato dos feitos coubesse unicamente aos juízes togados. Os militares apenas votavam, salvo raras exceções. Somente com o regime militar e a atribuição aos tribunais castrenses da competência para julgar os crimes ditos contra a segurança nacional é que os ministros militares passaram a relatar os feitos, por razões óbvias.

Prova da prescindibilidade da participação de militares no julgamento dos crimes militares encontra-se na órbita da Justiça Militar Estadual. Se na primeira instância os órgãos julgadores, nos estados, se organizam de maneira semelhante aos Conselhos de Justiça da Justiça Militar da União, sob a forma de escabinato ${ }^{17}$, o segundo grau de jurisdição é exercido, na maioria das unidades da Federação, pelo Tribunal de Justiça. Com efeito, apenas nos Estados de Minas Gerais, Rio Grande do Sul e São Paulo, onde o efetivo das Polícias Militares supera os 20 mil homens, há tribunais militares. Nos demais, é o próprio Tribunal de Justiça que julga, em grau de recurso, os crimes militares. Não há militares entre os julgadores e não consta que haja qualquer desvirtuamento - nem poderia haver - nos pronunciamentos jurisdicionais. A corte de civis aplica, sem problemas, a legislação penal militar (Melo Filho, 2002). 
A verdade é que o modo de funcionamento da Justiça Militar no Brasil, em particular o da União, constitui-se em injustificável exceção. Nela, disciplina e hierarquia militares transcendem os limites dos quartéis para terem assento no Poder Judiciário, que, via de regra, deveria estar adstrito aos limites do justo. De que importa a graduação se o que se pretende é a aplicação do direito onde se tem assegurado, por força constitucional, o princípio da isonomia? Além do mais, cumpre reconhecer que a atividade jurisdicional somente se perfaz de forma plena quando aqueles que devem exercê-la - os juízes, cuja missão lhes foi delegada pelo Estado - a realizam de forma imparcial e independente (Moura de Carvalho, 2002). Imparcialidade e independência que, com efeito, são vulneradas pelo critério de escolha dos integrantes do STM.

Na verdade, trata-se de típico caso de enclave autoritário no aparelho de Estado. Extinta a representação classista da Justiça do Trabalho, hoje, no Brasil, somente nos tribunais militares há a participação de leigos nos pronunciamentos jurisdicionais. A outra exceção é o Tribunal do Júri, que se destina exclusivamente ao julgamento dos crimes dolosos contra a vida. Ainda assim, não são poucas as críticas ao júri popular.

OSTM funciona como ator político relevante, não apenas pelo fato de seus membros serem juízes, mas também por serem militares da ativa. O ex-ministro da Justiça José Carlos Dias sentiu na pele o poder castrense. Dias, em fevereiro de 2000, anunciou ${ }^{18}$ que patrocinaria alterações no Código Penal Militar - CPM que foi editado pela Junta Militar em $1969^{19}$. Inclusive criou uma comissão para este fim $^{20}$. Partes do CPM não se ajustam à Constituição em vigor. Afora isto, há tipos penais que merecem revisão. $\mathrm{O}$ artigo 235, por exemplo, pune com prisão de seis meses a um ano quem praticar, em estabelecimento militar, "ato libidinoso, homossexual ou não".

Assim que o Diário Oficial publicou os nomes dos integrantes da referida comissão, o STM partiu para o ataque. O então presidente do STM, brigadeiro Sérgio Xavier Ferolla, não gostou de saber que a comissão havia sido criada sem que o tribunal fosse previamente consultado $^{21}$. Em face da reação, e com receio de deflagrar uma crise militar, Dias optou por dissolver a comissão ${ }^{22}$. A decisão foi tomada às pressas. Tanto é que as passagens aéreas para seus membros virem a Brasília já haviam sido emitidas ${ }^{23}$. Lamentando a perda da primeira 
oportunidade, na história do país, de discussão pública do Código Penal Militar, a advogada Sheila Bierrenbach foi taxativa: "Os fatos demonstram, inequivocamente, que a democracia no Brasil não se encontra consolidada. Antes os pit bulls andavam soltos. Agora, estão escondidos sob a pele de cordeiro" ${ }^{24}$.

Um outro episódio notório, fora da seara jurídica, envolveu o ministro brigadeiro Ferolla. Em novembro de 2000, o presidente Fernando Henrique Cardoso enviou tropas do Exército para proteger sua fazenda, localizada em Buritis (MG), contra possível invasão por parte do Movimento dos Trabalhadores Rurais sem Terra. O governador de Minas, Itamar Franco, interpretou esta medida como uma tentativa de desestabilizá-lo. Julgou que a polícia mineira é que deveria ser acionada. Preocupado, procurou apoio entre militares em Brasília. Dentre eles, o presidente do STM, brigadeiro Ferolla (Meireles e Miranda, 2000). Mais recentemente, Ferolla defendeu a criação da Agência Nacional de Aviação Civil, que retiraria a aviação civil do controle da Aeronáutica (Barbosa, 2004).

Outro exemplo revela a disparidade que pode haver entre decisões tomadas por um tribunal composto por militares e a posição de outra corte, integrada por civis, sobre um mesmo assunto.

A Lei no 9.299 foi sancionada pelo presidente Fernando Henrique Cardoso em 7 de agosto de 1996. Tal lei dispõe que a competência para o julgamento de crime doloso cometido por militares contra civis é da Justiça Comum. Ante a reação dos militares federais, treze dias depois o presidente Fernando Henrique Cardoso enviou ao Congresso o Projeto de Lei no 2.314, propondo a exclusão dos militares federais mas não dos militares estaduais - da Lei no 9.299/96.

Enquanto o Congresso não vota tal projeto de lei, o STM considerou inconstitucional a Lei no 9.299/96 e militares federais acusados de crime doloso contra civis continuam sendo julgados pelas Auditorias Militares ${ }^{25}$.

Por sua vez, o Superior Tribunal de Justiça, que julga, em grau de recurso, os crimes cometidos por policiais e bombeiros militares, não vislumbrou nenhuma inconstitucionalidade na lei. Tanto é assim que os policiais militares envolvidos na suposta chacina de Eldorado dos Carajás foram julgados pela Justiça Comum do Estado do Pará. 
Evidencia-se, aqui, sintomática divergência jurisprudencial, em decorrência da qual se estabelece curiosa distinção prática: a existência de dois tipos de militares, sendo os de primeira categoria os militares federais e os de segunda categoria, os militares estaduais. Embora ambos sejam militares, mesmo que cometam crime idêntico, serão julgados por tribunais e segundo leis penais distintas. Trata-se de decisão política, pois não há explicação ontológica para a distinção entre crime militar praticado por militar federal e crime militar praticado por militar estadual. Estranha quebra da isonomia, em um Estado de direito.

Merece registro, ainda, a transposição do princípio hierárquico para a jurisdição, como evidencia o fato a seguir narrado. No dia 4 de fevereiro de 1998, o então presidente do STM, general Soares Moreira, mandou lacrar a $4^{\mathrm{a}}$ Auditoria Militar Federal do Rio de Janeiro. Os prazos dos processos em tramitação foram suspensos, e os réus cujos prazos de prisão se esgotassem seriam liberados. O fio da história foi a punição administrativa da juíza Rosaly Cunha Machado Lira, que fora transferida para Bagé, por ter supostamente ofendido o presidente do STM durante diálogo telefônico. A juíza ficou conhecida em 1995, por ter denunciado o sumiço do livro de registro de armas e bens de presos políticos dos cartórios da Justiça Militar do Rio de Janeiro ${ }^{26}$.

Inconformada com a punição, a juíza recorreu à Justiça Comum e o juiz da $26^{\underline{a}}$ Vara Federal proferiu duas sentenças a ela favoráveis: uma anulando o processo administrativo e outra, em ação cautelar, garantindo o seu direito de voltar ao trabalho enquanto o recurso oposto contra a decisão na ação principal não fosse julgado. Rosaly Lira reassumiu suas funções no dia 8 de janeiro de 1998. O juiz que a substituiu, Mena Barreto Assunção, se encontrava de férias. Ao retornar, em 4 de fevereiro de 1998, deu-se o impasse: dois juízes para a mesma vaga.

Não se está analisando quem está correto, mas sim o fato de o presidente do STM, antes de esgotar os recursos legais, ter passado o cadeado na porta da Auditoria. Como lembrou Dias (1998), o Brasil é um país estranho: uma corte de Justiça presidida por um general da ativa desacata decisão judicial ${ }^{27}$. 


\section{Riocentro}

De acordo com a legislação penal militar, o arquivamento de um inquérito não impede a instauração de outro, se novas provas aparecerem. Novas provas surgiram dezoito anos depois daquele que poderia ter sido o maior atentado terrorista urbano da história brasileira: as explosões no Riocentro ${ }^{28}$. Mesmo assim o caso não foi reaberto.

Em 1999, o legista Elias Freitas, responsável pela necropsia do sargento do Exército Guilherme Pereira do Rosário, revelou, pela primeira vez, ter dito na ocasião ao encarregado do Inquérito Policial Militar do Riocentro, coronel Job Lorena, que a bomba explodira no colo do sargento. Lorena, todavia, divulgou (a) que o artefato explodira entre o banco e a porta direita do carro onde estava o militar e (b) que a bomba fora colocada por algum grupo terrorista (Otávio, 1999). Afora isto, o coronel da reserva da Polícia Militar, Ile Marlen, garantiu que, momentos depois da explosão da bomba, cinco agentes militares o procuraram. Queriam autorização para desmontar duas bombas instaladas no interior do pavilhão onde se realizava o show musical (idem).

Ante os novos fatos, a Comissão de Direitos Humanos da Câmara dos Deputados solicitou a reabertura do caso Riocentro. A procuradora da República Gilda Berger aceitou o pedido. Para Berger, o caso nem fora alcançado pela Lei da Anistia nem estava prescrito ${ }^{29}$, sem esquecer que o inquérito jamais se transformou em processo, condição sine qua non para os efeitos da Lei de Anistia. Diz o parecer da procuradora que a decisão do STM, em 1988, de enquadrar o caso na Lei de Anistia foi um autêntico erro in procedendo provocado pelo Ministério Público Militar (Seleme, 1999). Afinal, a validade da Lei de Anistia era até 1979, e o caso do Riocentro ocorrera em 1981.

A aprovação do relatório do Inquérito Policial Militar sobre os acontecimentos do Riocentro não fora algo pacífico. O almirante-de-esquadra Julio de Sá Bierrenbach, em 2 de outubro 1981, na qualidade de ministro do STM, votou contra o relatório elaborado pelo coronel Job Lorena. Logo após o voto, o ministro general-de-exército Reynaldo Mello de Andrade solicitou uma sessão secreta "na qual pudessem os ministros oriundos do Exército se manifestar de forma veemente contra o modo profundamente desrespeitoso como foram tratados, pelo Exmo. Sr. Ministro Bierrenbach, os chefes militares e, 
por extensão, o Exército durante sua manifestação em Sessão Pública" (Bierrenbach, 1996). No final da nota à imprensa então redigida, $o$ ministro general-de-exército Carlos Alberto Cabral Ribeiro deixou claro o caráter castrense do STM: "Resta-me, ainda, e finalmente, tornar bem claro que, nesta Egrégia Corte Castrense, continuo como General-de-Exército da Ativa e, nesta condição, com este protesto, tomo o meu efetivo lugar junto à Instituição ofendida injustamente [...]" (idem, ênfases nossas) $)^{30}$.

Diante da decisão da procuradora Berger de reabrir o caso, Bierrenbach assim se expressou:

"Infelizmente vivemos numa republiqueta e o caso nunca foi apurado com seriedade. Na ocasião, declarei que se o capitão Machado não se sentasse no banco dos réus ${ }^{31}$, como indiciado, o Ministério Público Militar ficaria desmoralizado. Meu desafio se renova agora, quando o órgão ganha nova oportunidade de passar esta história toda a limpo" (Otávio, 1999).

O STM, todavia, não atendeu, mais uma vez, às expectativas do almirante. Em 4 de maio de 1999, o caso Riocentro foi, mais uma vez, arquivado pelo ministro civil do STM Carlos Alberto Marques Soares ${ }^{32}$. Soares alegou razões técnicas: a existência de uma decisão do STM de 1988 que enquadrou o caso na Lei de Anistia. Como não houve recurso do Ministério Público Militar, permitiu-se a ocorrência do trânsito em julgado do acórdão ${ }^{33}$. O poder de punição do Estado teria cessado, pois a decisão tornou-se definitiva (Galucci, 1999). Ou seja, na visão de Soares, mesmo que surgissem novas provas, nada mais poderia ser feito, já que a sentença era definitiva.

A Procuradora-Geral da Justiça Militar Adriana Carneiro recorreu ao STM contra a decisão do ministro Soares ${ }^{34}$. OSTM, no entanto, manteve a decisão do ministro-relator por dez votos a um. O único voto contra veio de seu decano, o ministro civil Aldo Fagundes, que argumentou haver, tecnicamente, um fato novo: os militares, que antes eram apontados como vítimas, passaram a ser, em tese, supostos agentes, justificando a reabertura do caso. O argumento do ministro Fagundes foi repelido pelo ministro militar Arnoldi Pedrozo ${ }^{35}$ com uma argumentação política, em vez de jurídica. Para o general, já não existia a mesma preocupação em elucidar fatos como seqüestros de embaixadores feitos por organizações de esquerda durante o regime militar ${ }^{36}$. Só que tais seqüestros foram feitos durante o período abarcado pela 
Lei da Anistia, ao contrário, como visto, dos acontecimentos do Riocentro.

\section{Volta Redonda}

No dia 9 de novembro de 1989, com o intuito de pôr fim à greve dos funcionários da Companhia Siderúrgica Nacional - CSN, em Volta Redonda, o general José Luiz Lopes da Silva e suas tropas invadiram a siderúrgica ${ }^{37}$. Da operação resultou a morte de três operários que, por sinal, estavam trabalhando para manter os altos-fornos em atividade $^{38}$. Dez anos depois, o presidente Fernando Henrique Cardoso, atendendo a uma solicitação do Exército, indicou o general Lopes para o cargo de ministro do STM. Quem poderia ter sido indiciado pelas mortes dos operários se tornaria juiz.

AOrdem dos Advogados do Brasil, por intermédio de seu presidente, Reginaldo de Castro, enviou um telegrama a FHC protestando contra a indicação ${ }^{39}$. Segundo Castro,

“[...] a reputação ilibada que exige a Constituição Federal para a nomeação de magistrados impede a nomeação de quem teve qualquer envolvimento com ato criminoso passível de condenação judicial [...]. Estão os advogados brasileiros convencidos de que tais razões motivarão a substituição de seu nome para a composição do Superior Tribunal Militar" ${ }^{\prime 0}$.

Durante a sabatina na Comissão de Constituição e Justiça - CCJ do Senado, o general reafirmou que a operação, "sob o ponto de vista militar, foi plenamente bem-sucedida", que sua "paciência foi enorme" e que o "radicalismo" ocorreu do lado dos sindicalistas (Marques, 1999). Indagado pelo senador Eduardo Suplicy sobre o motivo de não ter utilizado balas de borracha, o general disse que o Exército não possui balas de borracha para reprimir protestos ${ }^{41}$. Mesmo assim, teve sua indicação aprovada por doze votos a favor, três contra e um em branco.

O bispo da diocese de Volta Redonda, Dom Waldir Calheiros, não se conteve ante a decisão da CCJ.

"O mais estarrecedor [afirmou] é que na mesma noite do massacre, eu, o prefeito da cidade e o presidente do sindicato fomos chamados pelo general para um encontro no hotel Bela Vista. Lá, questionamos a 
atuação do Exército e ouvimos dele que a morte dos trabalhadores pelo menos serviu de lição para o Brasil. Era um recado para os trabalhadores" (Pinheiro, 1999).

A cidade recolheu 15 mil assinaturas em um abaixo-assinado, enviado ao presidente da República, protestando contra a indicação do general (Guaraciaba, 1999).

Participou da pressão política para a aprovação do nome do general Lopes o então ministro extraordinário da Defesa, Élcio Álvares. Juntamente com o senador Antonio Carlos Magalhães, Álvares conseguiu alterar a tendência contrária à indicação de Lopes. Ante os parlamentares, Álvares argumentou que a não nomeação de Lopes deixaria o Exército em situação delicada (Lima, 1999). O general teve seu nome aprovado no Senado por 41 votos contra 24 e quatro abstenções. O novo ministro chegou ao STM como um lídimo representante do Exército no Judiciário.

\section{FARDADOS VS. TOGADOS}

Foi demonstrado que, em todos os momentos - à exceção de breve período, entre 1926 e 1934 -, os militares sempre foram maioria no STM. Sempre se buscou assegurar o predomínio dos militares, "ao mesmo tempo em que se procurou criar uma imagem de neutralidade, incluindo juízes civis [...] para criar a aparência de um tribunal misto" (Dallari, 1996).

A predominância de leigos, que se observa, também, no primeiro grau de jurisdição, inclusive da Justiça Militar Estadual, constitui exemplo único na estrutura do Poder Judiciário brasileiro. Mesmo na Justiça do Trabalho, à época em que existia a representação classista, os juízes togados sempre formaram a maioria nas cortes. No Tribunal Superior do Trabalho eram dezessete contra dez ministros classistas, proporção que se repetia nos tribunais regionais.

Outro aspecto de grande relevância é que, na Justiça do Trabalho, os leigos nunca estiveram no comando. A presidência, a vice-presidência e a corregedoria dos tribunais somente podiam ser exercidas por juízes togados, o mesmo ocorrendo nas Juntas de Conciliação e Julgamento, primeiro grau de jurisdição, onde a presidência cabia ao juiz de carreira. 
Na Justiça Militar, seja da União, seja dos estados, a presidência dos Conselhos (órgãos do primeiro grau de jurisdição) é exercida pelo militar de patente mais elevada. No STM, a eleição de um ministro civil para a presidência da corte somente veio a ser concretizada no ano de 2001, 193 anos após a sua criação.

De fato, até 1996 não havia sequer a hipótese de eleição de ministro civil para a presidência da corte. Eram eleitos, invariavelmente, para a vice-presidência. Foi nessa condição que, em 1963, o ministro Washington Vaz de Mello assumiu a presidência, exercendo-a por menos de três meses, em face da doença do titular.

Emenda regimental de 1996 determinou o ingresso de civis no rodízio, instituído, para os militares, em 1961. O primeiro ministro civil eleito presidente do STM foi o advogado Aldo Fagundes, que permaneceu no cargo por apenas dois meses. Para completar o biênio, foi eleito o ministro Olympio Pereira da Silva Júnior, empossado em 20 de junho de 2001. Ainda assim, cumpre ressaltar que o tribunal jamais foi presidido por um juiz de carreira, o que não deixa de ser estranho, tratando-se de uma corte de Justiça.

\section{A REFORMA DO JUDICIÁRIO E A JUSTIÇA MILITAR}

A Proposta de Emenda Constitucional - PEC no 96/92-A, de autoria do deputado Hélio Bicudo, do Partido dos Trabalhadores - PT de São Paulo, não prescrevia nenhuma modificação na estrutura da Justiça Militar Federal ${ }^{42}$.

O primeiro relator da PEC da reforma do Judiciário foi o deputado Jairo Carneiro, do Partido da Frente Liberal - PFL da Bahia. Em seu substitutivo, apresentado ainda em 1995, propunha alterações significativas não apenas na estrutura do STM, como também na sistemática de escolha dos seus membros.

Em primeiro lugar, previa como órgão da Justiça Militar, em tempos de guerra, um tribunal especial, mencionado no artigo 47, § 7․ Depois, dispunha que o STM teria, no mínimo, onze ministros - e não mais o número fixo de quinze--, sendo sete militares, dos quais três do Exército, dois da Marinha e dois da Aeronáutica - com o que se reduziria um cargo para cada Força -, e quatro civis. A indicação de todos os ministros necessitaria de aprovação do Senado Federal "em votação secreta, procedida, obrigatoriamente, avaliação circunstanciada 
do currículo e submetido o indicado a argüição pública para aferir o conhecimento e experiência compatíveis ao cargo" ${ }^{\prime 3}$.

Pelo substitutivo, os ministros militares seriam indicados em listas tríplices pelo Estado-Maior das respectivas Forças e os civis, entre brasileiros com mais de 35 e menos de 60 anos de idade, sendo dois entre advogados e dois entre juízes-auditores e membros do Ministério Público Militar da União. No caso dos advogados, para cada vaga seria elaborada uma lista sêxtupla pela $\mathrm{OAB}$ - observada a exigência de dez anos na carreira, notório saber jurídico e reputação ilibada -, a qual seria reduzida a três nomes pelo próprio STM. Os três nomes seriam então submetidos ao presidente da República, que indicaria um à aprovação do Senado. Tratando-se de juiz-auditor ou membro do Ministério Público, o próprio STM elaboraria a lista tríplice, procedendo-se, em seguida, da mesma forma já indicada. Haveria aí significativo avanço, porque, ao menos, haveria a participação da $\mathrm{OAB}$ e do próprio tribunal na escolha.

Esse relatório não foi aprovado. Diversas irregularidades formais e materiais foram apontadas e a PEC foi arquivada na Comissão Especial criada para o seu exame. Em 1999, a reforma do Judiciário foi retomada, com a instalação de Comissão Especial na Câmara. Designou-se para relator o deputado Aloysio Nunes Ferreira, do Partido da Social-Democracia Brasileira - PSDB de São Paulo.

A magistratura brasileira, por intermédio da Associação Nacional dos Magistrados - AMB, ofereceu sua contribuição para a reforma do Judiciário. Devem ser compreendidos os limites de ação da AMB neste caso, considerando-se que os juízes militares, da União e dos estados participam ativamente das deliberações da entidade. Ainda assim, não pode ser posto em discussão o caráter reformador de sua proposta.

De acordo com as sugestões da AMB (1999:127), seria reduzido para onze o número de ministros do STM, sendo seis militares e cinco civis. Destes, três seriam juízes de carreira indicados em lista tríplice pelo próprio tribunal. A presidência dos Conselhos de Justiça passaria aos juízes de carreira. Os crimes impropriamente militares seriam julgados, monocraticamente - sem a participação dos militares -, pelo juiz togado. 
Outros segmentos da sociedade organizada, especialmente os partidos políticos e a $\mathrm{OAB}$, buscaram participar ativamente, apresentando propostas integrais para a reforma. O Partido dos Trabalhadores, por exemplo, entregou a sua em abril de 1999. Nela propunha a extinção pura e simples da Justiça Militar, com a revogação dos artigos 122 a 124 da Constituição ${ }^{44}$.

Em audiência pública realizada no dia 28 de abril de 1999, o então presidente do STM, tenente-brigadeiro do Ar Carlos de Almeida Batista, fez vibrante defesa da Justiça Militar. Àquela altura, era palpável a possibilidade de extinção desse ramo especializado do Judiciário. Sabedor de tal risco, o presidente admitiu toda sorte de alterações, desde que mantida a estrutura por ele chefiada. Foram suas palavras:

“A Justiça Militar da União, desculpem-me a ênfase, não deve ser absolutamente extinta. Aceito, e até vejo como salutar, alguns ajustes que possam se mostrar necessários, como, por exemplo, uma adequação na composição da Corte, no método da escolha dos Ministros, na outorga da Presidência dos Conselhos de Justiça aos Juízes-Auditores" ${ }^{\prime 4}$.

O efeito da atuação do ministro Almeida Batista foi notável. O deputado Marcelo Deda, do PT, um dos signatários da proposta de extinção da Justiça Militar, assim se pronunciou:

“[...] sem dúvida alguma, a forma simples, direta e objetiva com que V. Exa. tratou da singularidade da função dos militares representou o primeiro argumento nesse debate que me levou a refletir sobre a convicção que já havia formado. [...] quero dizer sinceramente a V. Exa. que esse documento, pelo menos neste deputado, provocou a necessidade de rever minhas posições e verificar se elas resistem aos argumentos de V. Exa. [...] para justificar a existência do STM"46.

A partir de então, praticamente formou-se na Comissão Especial certo consenso quanto à redução da corte, sem extingui-la. O que terminou sendo proposto pelo relator.

Entre as diversas polêmicas alterações propostas em seu substitutivo, Aloysio Nunes Ferreira encaminhou alterações na estrutura da Justiça Militar ${ }^{47}$. Reduziu para sete o número de ministros, sendo quatro militares (um da Aeronáutica, um da Marinha e dois do Exército) e três civis. Não sugeriu nenhuma alteração para a indicação dos mili- 
tares. Para os civis, entretanto, propôs mudanças relevantes: seriam dois juízes titulares da magistratura de carreira, indicados, em lista tríplice, pelo próprio tribunal, e um ministro escolhido, alternadamente, entre advogados e membros do Ministério Público Militar, observado o disposto no artigo 94 da Constituição Federal ${ }^{48}$.

A atuação do deputado Aloysio Nunes Ferreira e a reação ao seu substitutivo, aliadas à necessidade de se promover a substituição do secretário-geral da Presidência da República, Eduardo Jorge Caldas, determinaram o afastamento do parlamentar da relatoria em 1999. Designou-se para substituí-lo a relatora Zulaiê Cobra Ribeiro, também do PSDB de São Paulo.

Novas modificações foram então propostas. Dentre elas, a redução do número de ministros para nove, igualando-se a participação das três Forças, pois seriam dois representantes de cada e três civis. Estes seriam escolhidos entre brasileiros com mais de 30 e menos de 65 anos de idade, sendo um advogado de notório saber jurídico e reputação ilibada e dois selecionados, por escolha paritária, entre juízes-auditores e membros do Ministério Público Militar ${ }^{49}$.

Tais alterações foram adotadas na Comissão Especial e aprovadas em plenário. A partir de junho de 2000, a PEC passou a tramitar no Senado sob o no 29/00. Depois dos pareceres de dois relatores, senadores Bernardo Cabral (PFL/AM), que mantivera a redação adotada na Câmara, e José Jorge (PFL/PE), e muitas discussões, deu-se por encerrado o trabalho na Comissão de Constituição e Justiça do Senado, em abril de 2004. Os representantes do STM conseguiram que o relator José Jorge fixasse em onze (e não em nove, como fora aprovado na Câmara), o número de ministros, sendo sete militares e quatro civis. Após aprovação em plenário, em dois turnos, a reforma foi parcialmente promulgada em 8 de dezembro de 2004. Em 31 de dezembro do mesmo ano foi publicada a Emenda Constitucional no 45/04. Tendo em vista que não houve coincidência entre os textos aprovados na Câmara e no Senado, no que respeita à composição do Superior Tribunal Militar, a matéria foi devolvida à Câmara dos Deputados. Caso seja rejeitada, a composição permanecerá inalterada, com quinze ministros. Uma vez aprovada, em dois turnos, o STM passará a ter onze ministros, sendo certo que disposição transitória determina que a adequação à nova composição se dará paulatinamente, com a vacância dos cargos. 


\section{CONCLUSÃO}

Um dos indicadores de uma relação civil-militar democrática é a existência de clara linha institucional de separação entre as jurisdições civil e militar (Rice, 1992). Stepan (1988) sugeriu que países que alcançaram reduzir a jurisdição militar antes da emergência de regimes autoritários e onde civis não estão sujeitos a julgamentos em tribunais militares conseguiram fazer a democracia avançar.

Por isso mesmo, as Justiças Militares de países democráticos não julgam civis em tempo de paz e só julgam os militares que cometeram crimes propriamente militares (Zaverucha, 1999). Ou nem possuem Justiça Militar em tempo de paz (Dinamarca, Finlândia, Noruega, Áustria, Alemanha). Constata-se que, quanto mais autoritário ou menos democrático for o país, maior a abrangência da jurisdição militar. A Justiça Militar, nestes casos, é usada como instrumento autoritário de controle social da população civil. De acordo com a Comisión Nacional de Verdad y Reconciliación, criada no Chile em 1990 pelo presidente Patrício Aylwin, um fator que facilitou os abusos cometidos durante a era Pinochet foi o Código Penal Militar ${ }^{50}$. Vários de seus artigos facilitaram a violação dos direitos humanos de muitos chile$\operatorname{nos}^{51}$.

No Brasil, a transição do autoritarismo rumo à democracia não teve o condão de determinar a redução da excepcional competência instituída pelo regime militar, mantendo a sua ampla jurisdição sobre civis em tempo de paz. Inalterada, restou a elástica tipificação do crime militar, construída no período de maior recrudescimento do regime autoritário, que permite, de um lado, a sua aplicação a civis e, de outro, a discriminação injustificável entre os integrantes das Forças Armadas e militares estaduais das Polícias Militares ${ }^{52}$.

Mas aqui não se pretendeu investigar as razões e as conseqüências de tais aspectos. Constituiu nosso foco de interesse não apenas a manutenção da Justiça Militar, da qual o STM faz parte, mas, principalmente, a conservação de grande parte da estrutura estabelecida no auge do regime militar, pelo Ato Institucional no 2, de 1965. E dos mesmos critérios de atuação e recrutamento de seus membros, marcado por elevado grau de interferência política.

Acresça-se que, em pleno século XXI, o STM continua a julgar civis por crimes militares cometidos em período de paz. Isto constrange o 
processo de criação de um Estado de direito no Brasil, pois os julgamentos militares tendem a favorecer a eficiência e certeza sobre a razoabilidade (Dershowitz, 2003). Afora que, em caso de dúvida, tais julgamentos favorecem, mais freqüentemente, os acusados do que os acusadores (idem).

O caráter híbrido da democracia brasileira, do qual o STM é um indicador, precisa ser explicado. Por que não avançamos rumo a uma democracia plena nem retrocedemos ao autoritarismo? Como explicar essa instabilidade que se vem mantendo ao longo de duas décadas?

Sugerimos introduzir a variável risco político. Como assim? Quando os conservadores acham que a esquerda ainda é, mesmo que parcialmente, revolucionária e que sua adesão à democracia é instrumental, procuram manter um relacionamento privilegiado com os militares (Alexander, 2002). Vínculo estreito que possa se reverter em apoio, quando necessário.

As invasões de terra por parte do Movimento dos sem Terra e o receio de que o mesmo caia na clandestinidade; a ocupação de prédios públicos pelo Movimento dos sem Teto e as greves das Polícias Militares, em especial das praças, são exemplos de fatos atuais que induzem desconfiança nos segmentos conservadores, prontos a se insurgirem contra qualquer risco de desmanche da economia de mercado, base da democracia liberal. Nesse contexto, a cultura do medo trabalha contra a democratização, pois induz desconfiança entre os atores políticos, em vez de cooperação. Quem tem medo tende a procurar segurança, como a propiciada pelo poder armado.

O receio decorrente da suposta imprevisibilidade da esquerda, em termos de atitudes democráticas, impele os atores políticos de direita a concordarem com a manutenção de espaços políticos significativos sob o controle militar, na expectativa de que tais arenas concorrerão, naturalmente, para a preservação dos seus interesses. Recentemente, o senador Antonio Carlos Magalhães defendeu com vigor, na tribuna do Senado, o aumento dos vencimentos dos militares. Alertou ele o governo Lula de que "essa defasagem salarial deve ser corrigida até para que, na hipótese de insubordinações populares, as Forças Armadas estejam prontas para defender as instituições" ${ }^{23}$. O senador voltaria ao tema dias depois, para afirmar que os militares são "o sustentáculo da democracia" ${ }^{\prime 5}$. 
Em síntese, a direita cuida de manter um bom relacionamento com as instituições coercitivas para que possam reprimir possíveis insubordinações populares e, no limite, golpear a frágil democracia existen$t^{55}$. Os militares entendem a natureza do jogo e cristalizam a estratégia de manter o seu protagonismo em arenas políticas não militares. Assim sendo, tornam mais explícita a simultaneidade dos interesses castrenses com os da sociedade.

Um desses espaços é o Superior Tribunal Militar. Não éà toa que a corte conservou praticamente inalterados sua estrutura, seu funcionamento e, principalmente, os critérios de recrutamento de seus membros durante o processo de redemocratização do país e na atual reforma do Poder Judiciário, oportunidade ímpar para a definição de novos parâmetros estruturais do tribunal e, até mesmo, para sua extinção. O que revela, de forma eloqüente, o poder de veto que detêm os conservadores, maioria no Congresso e interessados na manutenção do status quo, quando o assunto é a reformulação da Justiça Militar.

O STM, considerados os modelos competencial, funcional e estrutural vigentes, extrapola os limites de ação de um órgão do Judiciário, restritos à resolução de conflitos, para se erigir como instrumento de controle de importante aspecto da vida social. Em matéria criminal, o STM constitui-se em braço jurídico dos interesses institucionais das Forças Armadas, como evidencia o desfecho do caso Riocentro. Isto contribui para fortalecer, no Brasil, a existência de um governo pela lei (rule by law) em vez de um governo da lei (rule of law) (Holmes, 2003).

Tanto é que as Forças Armadas fazem questão de que a maioria dos juízes do STM seja composta por militares da ativa, exatamente porque, desse modo, podem controlar mais facilmente suas decisões. Este arranjo institucional, portanto, distribui poder em favor dos interesses das Forças Armadas, como instituição. E tais juízes são escolhidos com o fito de representá-las. Isto não impede que haja casos isolados de desafio à cúpula da instituição. Afinal, nem sempre os interesses das Forças Armadas são sinônimos dos interesses de todos os militares $^{56}$. Aí incluídos os juízes do STM.

Há o conhecido caso do general Peri Bevilaqua que, em pleno regime militar, tomou atitudes independentes, em relação aos interesses das Forças Armadas ${ }^{57}$. Seu comportamento não é a regra, mas a exceção. 
Tanto é que foi o único ministro afastado compulsoriamente do STM, em 1979, por medida baseada no AI-5, três meses antes de se aposentar por chegar à idade-limite para aposentadoria (Lemos, 2004) ${ }^{58}$. Do mesmo modo, ministros civis do STM podem, eventualmente, se comportar mais "militarmente" do que ministros fardados. Se assim o fizerem, colaborarão, ainda mais, para manter o STM como uma corte que defende, antes de tudo, os interesses das Forças Armadas relativos aos bens tutelados que lhes são fundamentais: hierarquia, disciplina e dever militar.

O Brasil situa-se em uma zona política cinzenta onde não se avança, definitivamente, no sentido de uma democracia sólida, nem se faz um retorno à ditadura. O STM é um típico exemplo desse hibridismo institucional, por possuir tanto características democráticas como autoritárias. Como vertente de ingerência castrense em área extramilitar -, no caso, o Judiciário -, o STM produz decisões eivadas de parcialidade, em um desvirtuamento de sua função jurisdicional, terminando por contribuir para postergar a consolidação da democracia no Brasil.

A eliminação do caráter militar do STM representaria mais do que mera filigrana constitucional. Antes, constituiria transformação de importante alcance político, considerando ser o Judiciário um dos Poderes do Estado. E poderia impulsionar outras mudanças institucionais no sentido de provocar o fortalecimento do Estado de direito e, conseqüentemente, o aprofundamento da democracia brasileira.

(Recebido para publicação em junho de 2004) (Versão definitiva em outubro de 2004) 


\section{NOTAS}

1. O comportamento militar é politicamente autônomo quando os militares têm objetivos próprios, que podem ou não coincidir com os interesses de outros grupos políticos, e capacidade institucional de executá-los, em detrimento de regras democráticas que proíbam a consecução desses mesmos objetivos.

2. O conceito de enclave autoritário refere-se a uma instituição que possui uma competência específica ou uma série específica de competências autônomas (Moyano, 1995). Em torno da instituição há leis, escritas ou veladas, que proíbem a interferência de forças políticas democráticas. Pode-se argumentar que as democracias procuram criar instituições imunes à influência de políticos, como no caso do Banco Central independente (Valenzuela, 1992). No entanto, o "enclave democrático" distingue-se do "enclave autoritário", principalmente, pela capacidade de as autoridades democráticas decidirem pela sua permanência ou não, sem receio de uma reação armada.

3. Recente pesquisa do PNUD, intitulada "A Democracia na América Latina", revela que o país vai bem em termos de democracia eleitoral, mas mal quanto à confiança na democracia. Apenas $30,6 \%$ dos brasileiros se consideram democratas; $42,4 \%$ são ambivalentes e $27 \%$ são não-democratas. Estes índices são os piores da América Latina. Vide http:/ / www.pnud.org.br/index.php?lay=news\&id01=286\&are=cid, "Brasil Consolida Eleições, mas População Tem Pouca Confiança na Democracia"; http:/ / www.pnud.org.br/index.php?lay=news\&id01=287are=cid, "AL Prefere Expansão a Regime Democrático".

4. Para uma ampla revisão da literatura sobre este tema ver Zaverucha e Teixeira (2003).

5. Ele apenas registra os conceitos, não fazendo uma diferenciação conceitual entre semidemocracia e semi-autoritarismo.

6. Artigo 70 do referido alvará.

7. A ser exercida pelo mais antigo na respectiva Arma. Até então, e desde 1920, como não havia aposentadoria compulsória e era permitida a reeleição, os eleitos permaneciam por muitos anos no exercício da presidência. O critério foi quebrado, na primeira oportunidade, em 1963, com a reeleição do tenente-brigadeiro Álvaro Hecksher, quando a presidência deveria caber a integrante da Marinha.

8. O tenente-brigadeiro Álvaro Hecksher, reeleito em dezembro de 1963, não concluiu o segundo biênio. Foi sucedido pelo almirante-de-esquadra Diogo Borges Fortes. A partir de então, e até hoje, tem sido respeitado o rodízio entre as Forças. A antiguidade nas Forças foi quebrada em 1979.

9. Existem 21 Auditorias, nas doze Circunscrições Militares existentes. Em cada Auditoria há um juiz-auditor e um juiz-auditor substituto, admitidos por concurso público de provas e títulos.

10. Informa Bastos (1981) que, à época, o Almanaque Anual do Exército trazia, além de outros assuntos, a composição de todas as repartições, entre as quais se incluía o Conselho Supremo Militar. Eis aí um forte argumento quanto à prevalência de sua feição administrativa.

11. Nos termos do artigo 7을 do Alvará de $1^{\circ}$ de abril de 1808. 
12. Sem dúvida, o funcionamento em turmas democratiza as decisões, na medida em que poderão surgir posicionamentos divergentes dentro da própria corte. Julgadas em órgão único, as mesmas matérias tendem a ter a mesma solução, sempre. Se há duas turmas, por exemplo, teoricamente poderá haver dissenso entre elas, o que quebra a rigidez jurisprudencial.

13. Na linguagem coloquial, "quarta estrela" é o posto mais alto que um oficial pode obter dentro da caserna.

14. A indicação do presidente Fernando Henrique Cardoso foi ilegal e inconstitucional. Tanto a Constituição como o Estatuto dos Militares dizem que um militar na reserva continua sendo um militar, e a legislação brasileira impede a presença de parentes em uma mesma sessão de julgamento. No caso, o irmão do coronel Aldo Fagundes já era juiz do STM. Como o STM é o único dos tribunais superiores que nãoé formado por turmas, não haveria modo de separar os dois irmãos.

15. Citado por Carlos de Almeida Batista. Cf. notas taquigráficas da Audiência Pública no 208/99 da Comissão de Reforma do Judiciário, p. 44.

16. Cf. notas taquigráficas da Audiência Pública no 208/99 da Comissão de Reforma do Judiciário, p. 47.

17. Forma de composição híbrida, integrada por civis e militares.

18. "Código Penal Militar Vai Ser Mudado", Jornal do Brasil, 13/2/2000.

19. Os Códigos Penal e de Processo Penal foram criados pelos Decretos-Leis $\mathrm{n}^{\mathrm{os}} 1.001 \mathrm{e}$ 1.002, datados de 29 de outubro de 1969. Portanto, criados no auge da repressão militar. Tais códigos, todavia, se encontram em pleno vigor em uma ordem dita democrática. Salvo engano, caso único no mundo.

20. Faziam parte da comissão o procurador da Justiça Militar João Rodrigues Arruda; a advogada Sheila Bierrenbach, representante da Ordem dos Advogados do Brasil; o ministro do STM Carlos Alberto Marques Soares; o juiz da 6 ${ }^{\underline{a}}$ Auditoria Militar do Rio de Janeiro, Cláudio Amim Miguel, e o defensor público Ariosvaldo de Góis Costa Homem.

21. Ferolla, mesmo sendo ministro do STM, também costumava discorrer sobre temas nada jurídicos. Por exemplo, nacionalista convicto, criticou publicamente a privatização de empresas como a Vale do Rio Doce e a Telebrás; a globalização exagerada; a elite brasileira, que, segundo ele, tem a "cabeça lavada" pelo "inimigo" (os Estados Unidos), e propôs que a Petrobras fosse uma empresa de energia e não apenas de petróleo (Rocha, 2000).

22. "STM Leva Ministro a Dissolver Comissão", Jornal do Brasil, 17/2/2000.

23. "STM Admite que Pressionou Ministro", Jornal do Brasil, 18/2/2000.

24. "Advogada Acusa Primo", Jornal do Brasil, 18/2/2000. Segundo a advogada, o intermediário da pressão sobre o ministro da Justiça teria sido seu primo, Flávio Bierrenbach, que fora recém-indicado para o STM por Dias, e que era compadre do mesmo.

25. O STM também entendeu inaplicável à Justiça da União a Lei dos Juizados Especiais Cíveis e Criminais: "Súmula no9 9- A Lei n⒐999, de 26.09.95, que dispõe sobre os Juizados Especiais Cíveis e Criminais e dá outras providências, não se aplica à Justiça Militar da União". Vide www.stm.gov.br. 
26. "STM Manda Fechar Auditoria Onde Juíza Denunciou o Sumiço de Armas e Presos", O Globo, 12/3/1998.

27. O conflito de titularidade ficou de ser dirimido pelo Tribunal Regional Federal. Enquanto isso, o procurador-geral da República recebeu ofício do procurador-chefe da Procuradoria da República no Rio e do procurador do caso, solicitando providências. Cf. "Magistrados Dão Apoio à Juíza que Foi Transferida", Jornal do Brasil, 13/3/1998.

28. O atentado do Riocentro ocorreu na noite de 30 de abril para 1으 de maio de 1981.

29. A anistia abrange apenas os crimes cometidos entre 2 de setembro de 1961 e 15 de agosto de 1979. A prescrição somente se daria em 30 de abril de 2001.

30. Por conta da nota, o ministro Ribeiro recebeu um telex do então ministro do Exército, general Walter Pires, felicitando-o pela defesa do Exército, "cujos quadros V. Exa. honra e dignifica" (Bierrenbach, 1996).

31. No IPM do coronel Lorena, Machado foi ouvido três vezes, como testemunha.

32. Para chegar ao STM, Soares, além de seus elevados conhecimentos jurídicos, contou com o apoio do então vice-presidente da República, Marco Maciel, e do ministro do Exército, general Zenildo Lucena.

33. O acórdão decretou a extinção da punibilidade dos responsáveis pela tentativa de atentado de 30 de abril de 1981. Teve por base a anistia geral concedida pela Emenda Constitucional $n^{\circ}$ 26, de 27 de novembro de 1985.

34. "Procuradora Recorre ao STM contra Arquivamento do Caso Riocentro", O Globo, 20/5/1999.

35. Quando tenente-coronel, Pedrozo era o encarregado da segurança do presidente Geisel. Foi ele quem contou a Geisel o destino de quatro argentinos e três chilenos capturados no Paraná. Gaspari (2003) reproduz o diálogo que teria havido entre Geisel e Pedrozo. O presidente diz ser preciso "agir com muita inteligência, para não ficar vestígio nesta coisa".

36. "STM Mantém Resolução que Arquivou o Caso Riocentro", Tribuna da Imprensa, $24 / 5 / 2000$.

37. A Polícia Militar do Rio de Janeiro é quem ficou na retaguarda do Exército, quando deveria ter sido o contrário.

38. Na ocasião, o ministro da Justiça quis abrir um inquérito para apurar as mortes, mas o ministro do Exército vetou o inquérito, contando com o apoio do presidente José Sarney.

39. "OAB Critica Escolha de General para o STM", O Globo, 9/10/1999.

40. “OAB Reprova Nome para o STM", Consultor Jurídico, 8/10/1999.

41. "Indicação de General para STM Gera Polêmica, mas é Aceita pela CCJ", Jornal do Senado, 7/10/1999.

42. Proposta de Emenda à Constituição no 96, de 1992, do deputado Hélio Bicudo, publicada no Diário do Congresso Nacional, 1/5/1992, pp. 7.857-7.947.

43. PEC 96-A de 1992, resumo do substitutivo do relator Jairo Carneiro, 5 de dezembro de 1995, p. 38. 
44. Proposta da bancada do Partido dos Trabalhadores na Câmara dos Deputados para a Reforma do Poder Judiciário, Assessoria Técnica do Partido, Brasília, 30 de abril de 1999, f. 24.

45. Notas taquigráficas da Audiência Pública nํ208/99, p. 48.

46. Notas taquigráficas da Audiência Pública n을 208/99, p. 111.

47. PEC 96-A de 1992, substitutivo do relator Aloysio Nunes Ferreira, 31 de maio de 1999, p. 55.

48. Exigência de dez anos de carreira, notório saber jurídico e reputação ilibada.

49. Reforma do Judiciário (PEC 96/92 e apensadas), substitutivo adotado pela Comissão Especial, deputada Zulaiê Cobra Ribeiro, novembro de 1999.

50. Para mais detalhes sobre a Justiça Militar no Chile, ver Pereira e Zaverucha (no prelo).

51. Informe de la Comisión Nacional de Verdad y Reconciliación. Santiago, 1991, p. 837.

52. A Emenda Constitucional no 18 , de 5 de fevereiro de 1998, extinguiu a expressão "policial militar", substituindo-a por "militar estadual". Algo que nem o regime militar foi capaz de fazer.

53. "ACM Alerta para os Baixos Salários das Forças Armadas", Jornal do Senado, 17/6/2004, ênfases nossas.

54. "ACM Defende Reajuste dos Vencimentos dos Militares", Jornal do Senado, $30 / 6 / 2004$.

55. Em julho de 2003, um dos proprietários da Folha de S. Paulo, ante a onda de invasões de propriedades rurais e urbanas, alertou para a possibilidade de o presidente Lula ser derrubado (Frias Filho, 2003). O líder do PSDB no Senado, Arthur Virgílio, comparou Lula ao ex-presidente Goulart (Dualibi, 2003). A mesma Folha de S. Paulo, na edição de 29 de julho de 2003, publicou afirmação do senador do PFL Romeu Tuma de que, se a situação ficasse incontrolável, pediria a intervenção militar.

56. Por exemplo, militar que assassinou colega dentro de quartel preferirá ser julgado por corte civil, pois, provavelmente, receberá sanção mais leve. Já para as Forças Armadas há o interesse em puni-lo exemplarmente.

57. Bevilaqua apoiou o golpe de 1964, mas se opôs à política repressiva do regime militar. Quis que o governo fosse logo devolvido aos civis.

58. A ira do regime militar contra Bevilaqua foi tanta que cassaram suas condecorações militares. Ele só as reaveria, postumamente, em 2002. 


\section{REFERÊNCIAS BIBLIOGRÁFICAS}

ALEXANDER, Gerard. (2002), The Sources of Democratic Consolidation. Ithaca, Cornell University Press.

AMB - ASSOCIAÇÃO DOS MAGISTRADOS BRASILEIROS. (1999), Propostas da AMB para a Reforma do Poder Judiciário. Brasília, Associação dos Magistrados Brasileiros.

BARBOSA, Mariana. (2004), “Ministro do STM Quer Controle Civil no DAC". O Estado de S. Paulo, 17 de janeiro.

BASTOS, Paulo César. (1981), Superior Tribunal Militar - 173 Anos de História. Brasília, Superior Tribunal Militar.

BIERRENBACH, Júlio de Sá. (1996), Riocentro. Rio de Janeiro, Domínio Público.

BRESSER PEREIRA, Luiz Carlos. (1998), “Da Administração Pública à Gerencial”, in L.

C. Bresser Pereira (org.), Reforma do Estado e Administração Gerencial. Rio de Janeiro, Fundação Getulio Vargas Editora.

COSTA FILHO, Milton Menezes da. (1994/1996), “A Justiça Militar no Poder Judiciário". Revista do Superior Tribunal Militar, vols. 16-18, Brasília, STM, pp. 35-56.

DALLARI, Dalmo. (1996), "A Polícia e as Garantias de Liberdade", in B.B. Moraes (org.), O Papel da Polícia no Regime Democrático. São Paulo, Mageart.

DERSHOWITZ, Alan. (2003), Why Terrorism Works. New Haven, Yale University Press.

DIAS, Maurício. (1998), “Informe JB”. Jornal do Brasil, 11 de março.

DUALIBI, Juliana. (2003), “Líder Tucano Compara Lula a Jango e Diz que Governo É 'Fraco e Arrogante'”. Folha de S. Paulo, 31 de julho.

FRIAS FILHO, Otávio. (2003), "Lei e Ordem". Folha de S. Paulo, 31 de julho.

GALUCCI, Mariângela. (1999), "STM Arquiva Inquérito sobre Riocentro". O Estado de S. Paulo, 5 de maio.

GASPARI, Elio. (2003), A Ditadura Derrotada. São Paulo, Cia. das Letras.

GUARACIABA, Mirian. (1999), “O Brasil Esqueceu Volta Redonda”. Correio Braziliense, 8 de janeiro.

HELD, David. (1987), Modelos de Democracia. Belo Horizonte, Ed. Paidéia.

HOLMES, Stephen. (2003), “Lineages of Rule of Law”, in J.M. Maravall e A. Przeworski (eds.), Democracy and the Rule of Law. Cambridge, Cambridge University Press.

LEMOS, Renato (org.). (2004), Justiça Fardada - O General Peri Bevilaqua no Superior Tribunal Militar (1965-1969). Rio de Janeiro, Bom Texto.

LIMA, Maria. (1999), "Senado Aprova Indicação para STM de General que Invadiu CSN". O Globo, 21 de outubro.

MAINWARING, Scott, BRINKS, Daniel e PÉREZ-LIÑAN, Aníbal. (2001), “Classificando Regimes Políticos na América Latina". Dados, vol. 44, no 4 .

MARQUES, Hugo. (1999), "Eleito General que Dirigiu Ação em Volta Redonda". O Estado de S. Paulo, 7 de outubro. 
MEIRELES, Andrei e MIRANDA, Ricardo. (2000), "O Monstro se Mexe no Porão". Istoé, 19 de novembro.

MELO FILHO, Hugo Cavalcanti. (2002), A Independência Judicial como Fenômeno Positivo para a Democracia. Dissertação de Mestrado em Ciência Política. Universidade Federal de Pernambuco, Recife.

MOURA DE CARVALHO, Fernanda. (2002), Justiça Militar - Parcialidade e Dependência. Monografia do I Curso de Especialização de Gestão em Defesa Social. Fundação Joaquim Nabuco, Recife.

MOYANO, Maria José. (1995), Argentina's Lost Patrol: Armed Struggle 1969-1979. New Haven, Yale University Press.

OTÁVIO, Chico. (1999), "Legista Desmente IPM do Riocentro". O Globo, 11 de abril.

PEREIRA, Anthony e ZAVERUCHA, Jorge. (no prelo), "The Neglected Step-Child: Military Justice and Democratic Transition in Chile". Social Justice, vol. 32, n-2 2, julho.

PINHEIRO, João. (1999), “Bispo Ataca Ida de General para STM". Jornal do Brasil, 14 de outubro.

PRZEWORSKI, Adam, ALVAREZ, Michael, CHEIBUB, José Antonio e LIMONGI, Fernando. (2000), Democracy and Development: Political Institutions and Well-Being in the World, 1950-1990. Cambridge, Cambridge University Press.

RICE, Condoleezza. (1992), “The Military under Democracy”. Journal of Democracy, vol. $3, \mathrm{n}$ 을 abril, pp. 27-41.

ROCHA, Leonel. (2000), “Entrevista Ferolla". Istoé, 3 de julho.

SCHUMPETER, Joseph. (1942), Capitalism, Socialism and Democracy. New York, Harper.

SELEME, Ascânio. (1999), "STM: Retomada Depende de Fato Novo". O Globo, 12 de abril.

SOARES, Carlos Alberto Marques. (1994/1996), “A Justiça Militar Federal”. Revista do Superior Tribunal Militar, vols. 16-18, Brasília, STM, pp. 121-135.

STEPAN, Alfred. (1988), Rethinking Military Politics. Princeton, Princeton University Press.

VALENZUELA, J. Samuel. (1992), “Democratic Consolidation in Post-Transitional Settings: Notion, Process, and Facilitating Conditions", in S. Mainwaring, G. O'Donnell e J. S. Valenzuela (eds.), Issues in Democratic Consolidation. Notre Dame, University of Notre Dame Press.

ZAVERUCHA, Jorge. (1994), Rumor de Sabres. São Paulo, Ática. (1999), "Military Justice in the State of Pernambuco after the Military Regime: An Authoritarian Legacy". Latin American Research Review, vol. 34, n으 2. . (2000), Frágil Democracia: Collor, Itamar, FHC e os Militares. Rio de Janeiro, Civilização Brasileira.

e TEIXEIRA, Helder B. (2003), “A Literatura sobre Relações Civis-Militares no Brasil (1964-2002): Uma Síntese". Revista Brasileira de Informação Bibliográfica em Ciências Sociais - RBIB, $\mathrm{n}-55,1$ 을 semestre. 


\begin{abstract}
The Superior Military Court: From Authoritarianism to Democracy

This article aims to demonstrate how the Brazilian Superior Military Court of today (just as under the former military regime) continues to primarily defend what it considers the most important assets under its tutelage: hierarchy, discipline, and military duty. The Court has hybrid characteristics, displaying traits both from the authoritarian regime as well as from Brazil's current fledgling democracy. It is no coincidence that the Court has maintained its structure, functioning, and recruitment criteria virtually unaltered. The article contends that this institutional hybridism can only be overcome when effective democratic civilian oversight of the military is achieved.
\end{abstract}

Key words: military justice; armed forces; authoritarianism; democracy

\title{
RÉSUMÉ
}

Le Tribunal Militaire Supérieur: Entre L'Autoritarisme et la Démocratie

Dans cet article, on cherche à montrer que, comme pendant les années du régime militaire, le Tribunal Militaire Supérieur continue à défendre, avant tout, les intérêts constitutionnels de l'Armée ayant rapport aux biens placés sous sa tutelle qui leur semblent importants: hiérarchie, discipline et devoir militaire. Le Tribunal Militaire Supérieur est un tribunal à caractères hybrides, présentant des traits issus non seulement du régime autoritaire mais aussi de la fragile démocratie brésilienne. Ce n'est pas un hasard si la Cour en a conservé pratiquement inchangés la structure, le fonctionnement et les critères de recrutement de ses membres. On suggère que le dépassement de cet hybridisme institutionnel n'aura lieu que si, effectivement, on réussit à établir un contrôle civil démocratique sur les militaires.

Mots-clé: justice militaire; armée; autoritarisme; démocratie 